\title{
Psciendo
}

\author{
Przemysław Żukiewicz \\ Uniwersytet Wrocławski
}

\section{ADMINISTRATION OF URBAN PUBLIC TRANSPORT IN THE LARGEST POLISH CITIES}

DOI: $10.2478 /$ ppsr-2020-0016

\begin{abstract}
Author
Przemysław Żukiewicz - professor of comparative politics and director of the Data and Social Networks Lab at the University of Wrocław; visiting fellow at the Dublin City University (2017/2018) and former Secretary-General of the Polish Political Science Association (2016-2018); principal investigator in research projects focused on general system theory, public leadership, social networks and mobility policy.

ORCID no. 0000-0001-7579-4341

e-mail: przemyslaw.zukiewicz@uwr.edu.pl

Abstract

In this article, we compare the solutions which the largest Polish cities apply to effectively manage and administer public urban transport. We pay attention to the legal, administrative, and political limitations of current activities; we also analyse public transport strategies in terms of plans for the future. We state that large Polish cities prefer to entrust public transport services to fully dependent companies, do not seek to diversify service providers and do not allow the coexistence of public and private operators. Our research is the first comparative study which has used the eleven largest Polish cities as a research sample. Its results are important not only for decision-makers, but also for entrepreneurs in the transport industry. Not only does our analysis prove that, currently, urban transport in the largest Polish cities is carried out mostly by companies which fully belong to cities, but also that the future strategies of the target state will not be determined by political decision makers at all, or no significant changes are foreseen. In the largest Polish cities in the future, the tramway sector will be fully controlled by municipal companies; in the bus transport sector, private carriers will be able to count on a maximum of $20-30 \%$ share of transport work while the railway sector will remain under the control of regional administration, not local urban administration.
\end{abstract}

Keywords: public policy; public administration; mobility policy; transportation networks; urban public transport; Poland

\section{Introduction}

Public transport is rarely of interest to public administration and public management researchers. There is a perception that this is an area of analysis appropriate to the engineering sciences (safety, technology of transport, infrastructure) or life sciences (noise level, propulsion, exhaust emission). Even if the topic is discussed by representatives of the social sciences, it is sociologists who are more likely to do so (research on the city and the transportation behaviour of residents), or economists (analyses regarding the profitability of adopted solutions) or psychologists (human resources in transport). 
Meanwhile, issues related to transport are an important element of the legal, administrative, and political system not only for each state, but also for supranational institutions, regions and municipalities: "Overlap" of these solutions and the divergent interests that they reflect can sometimes cause collisions of legal norms and the ineffectiveness of enforcing responsibility for the implementation of specific solutions. This in itself is a very interesting field of research, which is rarely explored in such a comparative or confrontational dimension. The literature is dominated by normative analyses of individual cases (Kowalski et al. 2013; Sońta 2012). However, there is no answer to the question of how specific legal solutions are implemented at various levels of administration (transnational, central, regional, and local) and no identification of areas of tension that may be related to this implementation.

The purpose of this article is to show how the authorities of Polish cities implement in practice - in relation to the organization of public urban transport - the rules set out in the regulation of the European Parliament and the Council of the European Union on public passenger transport services by rail and by road, as well as in the act on collective public transport. We are interested in both the current situation, which is why we recapitulate the legal status in relation to applicable laws and the state of affairs in the public transport management practices in cities, and in the target situation, which is why we analyse plans for sustainable development of public collective transport, in which strategies for its development are included.

We applied the method of dogmatic legal analysis with reference to the aforementioned regulation of the European Parliament and the Council of the European Union as well as the law on public collective transport passed in Poland in 2010. We verify the hypothesis that the diverging assumptions regarding public transport organization in Poland were guided by the EU legislator (objectives: liberalisation, deregulation, privatisation) and the Polish one (goals: control, status quo, centralism). We also show-through examples of the eleven largest Polish cities: Warszawa, Kraków, Łódź, Wrocław, Poznań, Gdańsk, Szczecin, Bydgoszcz, Lublin, Białystok and Katowice - how it affects the administration of urban public transport. The source of information was primarily legal acts:

a) legal acts of transnational rank/of international importance available on the websites of European Union institutions and the Polish parliament;

b) acts of local law available in the Public Information Bulletins of Polish offices;

c) internal acts (statutes and regulations) of institutions or companies that deal with the management or administration of urban public transport, available on the websites of these entities.

In addition, we analyse the content of eleven transport plans that Polish cities had to enact to manage public urban transport more effectively. At the end, we formulate conclusions, bearing in mind that the process of creating a law on public transport is still not complete.

The analysis presents, on the one hand, the importance of the legal norms in the administration and management of public urban transport, and, on the other hand, a review of actually adopted solutions, placing it on the borderline of public administration sciences and public management science. Similarly to Timothy Endicott, we believe that administrative law is crucial to establishing a good governance framework, but at the same time administrative law supports good governance only indirectly: by assigning responsibility 
to the government for specific actions (Endicott, 2015, p. 15). The effectiveness of specific solutions - especially at the local level-is a derivative of social, political and economic factors on which legislators at the macro level have a very limited impact (Cantwell et al., 2009; Fellesson and Friman, 2012; Uspalyte-Vitkuniene and Burinskiene, 2007).

\section{Theoretical frames and literature review}

The subject of our research is the model of public urban transport management adopted in the largest Polish cities. We are looking for similarities and differences occurring in the legal framework designated on the one hand in the European regulations, and on the other hand by national legislation. The fact that cities in the same legal system prefer different management solutions has already been demonstrated in Polish subject literature (Dydkowski, 2015, pp. 45-46), nevertheless there is still a lack of: a) the presentation of current data regarding the situation after subsequent amendments to the act on public collective transport; b) English-language texts devoted to Polish experiences that could form the basis for comparative analyses; c) a comparison of the current actual state with the desired state expressed in the development strategies of individual cities.

Our research is of a comparative nature because local solutions adopted in individual cities have both common and differing features. We assume that within the Polish legal system there are specific subsystems of law in the field of public urban transport determined by acts of local law and internal statutes and regulations that affect the appearance of differences between individual cities. In this sense, our analysis fulfils the basic requirement of legal comparative studies defined in classical methodological works (Kahn-Freund, 1974, pp. 2-3; Kamba, 1974, p. 487).

In order to strengthen the argument for recognizing cities as local legal subsystems, it is necessary to emphasise the importance of the political processes of emancipation and development of both cities and agglomerations, which become key players in the globalised world that affects the quality of the everyday life of residents. This thesis is reflected not only in the increasing rank of acts of local law, but also in the findings of political and sociological research. Benjamin Barber predicted that cities and their leaders may become an antidote to the most serious problems of the globalised world (Barber, 2017, 2014). Literature regarding the key role of cities in the modern world is actually much richer (Glaeser, 2011; Katz and Bradley, 2014).

This article assumes that the organization and administration of urban public transport is the result of ideas, institutions, and political interests.. This view is shared by the authors of comparative analyses of urban transport in France and Switzerland. They indicate the fact that inadequate coordination of these levels may lead to inertia in the field of spatial planning and adaptation of spatial management plans to the mobility needs of residents (Gallez et al., 2013).

As part of the subject literature review, we have identified several topics in particular that are readily undertaken by researchers. We have also observed that very little space is devoted to the comparison of applied solutions in the management and administration of urban public transport.

The closest to our considerations were the works devoted to the influence of legal regulations on the provision of services by the state or private entities, and on the degree of deregulation of the public transport sector. It was Zatti who drew attention to the impor- 
tance of public administration in the management of local transport. According to his research, despite the existence of legal instruments of the European Union and the Europeanisation processes in the cases of public local transport analysed by the researcher, the liberalisation of the market and privatisation of the services did not occur. According to Zatti, decision-makers and experts should focus on providing these services publicly, with the realisation that private operators will always be only contractors of the service ordered, not creators of innovative solutions (Zatti, 2012).

Massey came to similar conclusions despite the fact that he analysed not just the local bus segment. The researcher said that the introduction of the Public Transport Regulation Act in Ireland in 2009 did not result in the de-monopolisation and reduction of bus services. Pursuant to the provisions of the act, this market was supposed to become subject to free competition rules in 2013. However, because of political and administrative pressures this deadline was postponed to 2019 (Massey, 2014).

It is worth paying attention to the studies that prove the significant impact of institutional changes on the quality of urban public transport. Gualdi and Sessa support that, by proving that the establishment of the Integrated Planning Agency (STA) in Rome in the 1990s resulted in the implementation of new innovative transport plans. This, in turn, forced changes in the current system (Gualdi and Sessa, 2002). In Poland, an interesting problem was noticed by Rek-Woźniak (2017), who showed that many infrastructural projects related to public transport do not respond to the real needs of potential users, but are a derivative of the vision and dreams of the powers that be of the city.

In recent years, more and more attention has been paid to the issue of organising public transport in the concept of a smart city. The subject literature emphasises the importance of such factors as the convenience of using interchanges (Heddebaut and Di Ciommo, 2018), the need to integrate various forms of public transport through the use of a common tariff, shared routes, shared stops or the introduction of tram-trains (Solecka, 2011). In this context, we should also see in-depth analyses of political activities at the central, regional, and local levels regarding the promotion of sustainable development, including in particular the introduction of modern and innovative tools to reduce excess emissions (Grondys et al., 2017).

What remains is the involvement of residents in the process of deciding on urban public transport, which is an important factor in the development of cities. The Community bus project presented on the example of Tokyo by Khan and Khan, was to serve this purpose. In their opinion, the optimal model for the development of public urban transport in such a big city is a possibility for local communities, public administration, and private carriers to decide how to organise a network of connections and who should offer their services within it (Khan and Khan, 2012). Also, Sager analysed various models of deliberation in European metropolitan areas (Sager, 2005). On a local scale (a comparative analysis of Polish and German cities), research was also carried out, and good practices were indicated in the process of including residents in the process of managing the transport network (Tomaszyk, 2016). It is also worth paying attention to studies proving how information technology tools can help in informing users about access to transport services, and thus reduce the risk of social exclusion (Turner et al., 2000).

The last research stream to which we refer to are works devoted to changes in the administration of public urban transport in Poland (Dydkowski, 2015; Sopoćko et al., 2016; Taylor and Ciechański, 2015, 2010, 2009). This topic was discussed only in Polish-language 
journals. In an English-language report devoted to the identification of local transport development paths, which Zatti drafted in 2011, Poland is referred to as a country in which local transport is privatised only to a small extent. The research was carried out in three cities: Warsaw, Kraków and Elbląg. Zatti drew attention to divergent legal regulations and diversified results of reforms that were achieved in these individual cities. He decided that Poland could not be qualified for any of the distinguished ideal types: neither would it follow the path set by European standards (liberalisation, decentralisation, privatisation), nor does local transport remain fully state-owned (Zatti, 2012, p. 544).

\section{Research methodology}

\section{Research procedure}

At the beginning, we analysed the European Union regulations regarding the organization of public urban transport and the process of creating and amending the act on public transport called UPTZ (UPTZ-ustawa o publicznym transporcie zbiorowym,). It is a legal act in Poland which comprehensively regulates the issue of organising and administering public transport in cities.

We then attempted to determine the actual state of affairs related to the organisation and administration of public urban transport in Poland. We analysed internal documents of transport organizers and transport operators, as well as the official information presented on the websites of these entities. Subsequently, we analysed eleven documents defining the strategic framework for the development of urban public transport in Polish cities (so-called transport plans). The key point of the content analysis was to look for answers to the question of what the distribution of tasks between public and private operators would ultimately look like.

We chose the eleven largest Polish cities for analysis. The only criterion for selection was the number of inhabitants recorded in December 2018. On one hand, we are aware of the limitations that are associated with such a categorisation key, but on the other-we wanted to present a spectrum of solutions that the municipal authorities have adopted in terms of administering urban collective transport. In other words: we wanted to go beyond the perspective of case studies (very common in this type of analysis concerning Poland) and a comparative perspective focused on a small number of objects. In Poland, however, Taylor and Ciechański $(2014,2015)$ conducted comparative research on the ten largest Polish cities in Poland, but they were related to other issues.

\section{Characteristics of a research sample}

According to the Central Statistical Office data, the most populous cities in Poland on December 31, 2018 were Warszawa, Kraków, Łódź, Wrocław, Poznań, Gdańsk, Szczecin, Bydgoszcz, Lublin, Białystok and Katowice (GUS, 2019, p. 100).

The population numbers of these Polish cities - excluding the capital-varies between $\sim 300,000$ and 750,000 inhabitants. The east of the country is clearly under-represented in this analysis - most of the big cities are located in western and central Poland. It should also be emphasised that three of these cities are characterised by their specificity. Warsaw is the capital and clearly has a larger number of residents than the other cities, which 
affects not only the city public transport system itself, but also the administrative status of the city. It is regulated by a special law for the system, which is typical of a capital city (UMSW, 2002). Gdańsk is the largest city of Pomerania, but together with Gdynia and Sopot it forms the metropolitan area of Tri-City, which together has almost 750,000 inhabitants. Finally, Katowice, the capital of the Silesia Region, cannot be analysed in terms of its transport system without taking into account the fact that together with 40 other cities they form the GZM Metropolis (Górnośląsko-Zagłębiowska Metropolia). It consists of other towns with populations of over 100,000, such as Gliwice, Sosnowiec, Ruda Śląska and Bytom. In total, the metropolis is inhabited by nearly 2.3 million people (ZMWŚ, 2017).

In nine of the cities analysed, public urban transport is served by buses and trams. The metro operates only in the capital. There is no tram network in Lublin and Białystok, however, there is a trolleybus network in the former. In addition, there are two regular water-tram lines in Gdańsk, and one gondola lift in Wrocław. The traditional railway has an important feeder function, but it is recognised supra-local because it supports more than one municipality. Only in Warsaw and Gdańsk are there railway companies responsible for transporting people by agglomeration trains, not regional ones (Fast Urban Railway). A similar project was initiated by the non-governmental organization "Poznan Metropolis" and it is dedicated to the development of the metropolitan railway system around Poznan city (Poznań Metropolitan Railway).

\section{Public urban transport in a Polish legal system}

The European Union regulations do not regulate public transport issues in a clear and precise manner. However, one can speak about the form of indirect influence of European economic, cultural, and social norms that many European cities try to implement in the field of organisation and administration of public transport. Historical analyses point to the unambiguously liberal nature of the transformation of the European transport policy sui generis ${ }^{1}$ - one can observe the efforts of the EU institutions to de-monopolise, commercialise and privatise individual segments of the transport market (Giorgi and Schmidt, 2006). However, awareness of the social utility of urban transport and its cost-intensive nature, means that the emphasis on the liberalisation of this market is much smaller than for the others. That is why in the vast majority of cities, the dominant model is the public provision of transport services and the limited presence of private entities in this sector.

Maintaining this balance is primarily based on art. 93 of the Treaty on the Functioning of the European Union, which allows assistance that would meet the needs of coordination of transport or would be a reimbursement for the performance of services inseparably connected with the concept of a public service. At the same time, the provisions of the Treaty oblige Member States to comply with the rules of competition (TFEU, 2007, art. 106: 2).

The regulations of the European Union, however, strictly define the terms of cooperation between public institutions and their subsidiaries and private entities, insofar as it concerns public transport in cities. In accordance with the Ordinance of the European Parliament and the Council of October 23, 2007, the local authority independently decides whether public passenger transport services are provided by itself or are provided by

1 The European Council under so-called the Lisbon process of 28 March 2000 called on the Commission, the Council and the Member States, within the limits of their respective competences, to „speed up liberalization in areas such as transport". 
an internal entity of this body without a tender (PPTS, 2007, art. 5: 2). In both cases, these bodies may not participate in tenders organised outside their own jurisdiction. It is also possible to conclude subcontracting agreements as well as entrusting third parties with services in this area.

It is worth noting that in Poland, as in many other Central and Eastern European countries, public transport issues are not included in the constitution, despite the wide range of social rights guarantees: social security, equal access to publicly funded healthcare services, free of charge education, a pro-family policy and support for social housing. Regulations regarding transport-both in relation to local government units as well as in relation to the central level-are included primarily in the act on public collective transport and in the implementation of the regulations for this legal act. Each municipality and every region also have local law acts on the basis of which public transport activities in a given area are organised.

In accordance with the act, the municipalities have the obligation to organise transport on their territory (USG, 1990, art. 7: 1: 4). The way in which the municipality should carry out its task is determined by the act on public transport passed in 2010, but since then amended many times. Negotiations with operators and organisers of local transport also resulted in some of its provisions having a seven-year period of vacatio legis.

The most important issues regulated in the act on public road transport concern the definition of the concept of public transport and the separation of entities responsible for public transport in each local government unit, along with the division between the public transport operator and the organiser of public collective transport. Public transport is understood as "municipal passenger transport carried out within the city's administrative borders or:

a) a city and a municipality,

b) a city, or

c) cities and neighbouring municipalities

- if an agreement has been concluded or an inter-municipal association has been established for the purpose of joint implementation of public collective transport, as well as metropolitan passenger transport" (UPTZ, 2010, art. 4: 1: 4).

The operator of public collective transport is, on the other hand, a self-governing budget company and an entrepreneur authorised to run a business in the field of passenger transport, who has concluded an agreement with the organiser of public collective transport for the provision of public mass transport services on the transport line specified in the contract (UPTZ, 2010, art. 4: 1: 8).

In accordance with Polish law, the organiser of public collective transport is the competent local government unit or the minister responsible for transport, ensuring the functioning of public transport in a given area (UPTZ, 2010, art. 4: 1: 9).

According to UPTZ, the organiser can choose an operator based on:

1. the result of the tender conducted in accordance with the Public Procurement Law;

2. allocation of a concession in accordance with the act on Concessions for Construction Works or Services;

3. direct conclusion of the contract if:

a) the average annual value of the contract does not exceed EUR 1,000,000, or the services do not exceed 300,000 kilometres per year. The given values may be doubled in the case of contracts with small operators with fewer than 23 means of transport; 
b) the provision of public collective transport services is to be performed by an internal entity;

c) the provision of services is to be performed in rail transport;

d) there will be a disruption or a risk of disruption in the provision of services, however, such a contract may be concluded for no more than two years (UPTZ, 2010, art. 19 and 22).

UPTZ requires organisers to develop plans for sustainable transport development. In the act, the legislator has defined the necessary elements of such a plan. These include, among others, the definition of a transport network, an assessment and forecast of transport needs, a desirable standard of transport services and rules for the organisation of the transport market (UPTZ, 2010, art. 12).

\section{Management and administration of municipal public transport in Polish cities - current status}

\section{Organisers}

Pursuant to the act on municipal self-government, ensuring local transport is the municipality's own task. The organiser of the transport is actually its executive body: in big cities in Poland, it is the mayor. In eight of the analysed cities, he appointed a special budgetary unit for this purpose. Differences between cities mainly concern whether such a budgetary unit has only the organisation of transport within its scope, or else also the development of infrastructure, i.e. investments related to the maintenance of roads and other transport engineering facilities. It is not possible to clearly indicate which factors have caused the choice of a certain solution: it is not correlated with either the number of inhabitants or the urban area. It should be assumed that many years of management practices were referred to, without an attempt to violate the status quo.

This issue was resolved separately in Wrocław and Białystok. In these cities, the transport departments, which are internal office units, not separate budgetary units, are responsible for organising the transport. In Katowice, the most important department is inter-municipal transport, not urban transport. Therefore in 2019, as part of the inter-municipal agreement, Zarzad Transportu Metropolitalnego (the Board of the Metropolitan Transport) was established, which performs the tasks of the public transport organiser not only in Katowice, but in the other towns and cities of the Upper Silesia-the Coal Basin Metropolis.

\section{Operators}

In Warsaw, there was a diversification of entities providing services, but only in the case of the bus transport sector. Miejskie Zakłady Autobusowe (Municipal Bus Company) is the main organiser of transport with $72 \%$ of the market share, while $28 \%$ belongs to private entities selected through tender and operators performing services on the basis of an agreement between Miejskie Zakłady Autobusowe and the suburban municipality. The operator of the tram segment is the urban company Tramwaje Warszawskie (Warsaw Tramways), which has contracted services until 2027, at which point Metro Warszawskie (War- 
saw Metro) will be the operator of the metro line in the capital city. Warsaw is the only Polish city that has decided to isolate the operator in the railway sector. It is a city company Szybka Kolej Miejska (Fast Urban Railway), which will provide services up to 2024. The company operates independently from other regional and national railway companies.

The operators in Krakow in the bus sector are: the municipal company, Miejskie Przedsiębiorstwo Komunikacyjne in Krakow (Municipal Transport Company), which has services contracted until 2020, and a private company Mobilis, with which the city signed a contract for the provision of transport services on 12 bus lines until 2024. In the tram sector, the only operator (until 2020) remains Miejskie Przedsiębiorstwo Komunikacyjne in Kraków. Kraków does not have a separate operator responsible for transport in the railway sector. At the regional level, Koleje Małopolskie (Małopolskie Railway) performs this function.

The only transport operator for bus and tram services in Łódź is Miejskie Przedsiębiorstwo Komunikacyjne (Municipal Transport Company). The tram sector service has been contracted until 2026, and the bus sector until 2021. At the request of another organiser (Miejskie Ustugi Komunikacyjne w Zgierzu, Municipal Transport Services in Zgierz), Zgierskie Przedsiębiorstwo Komunikacyjne Markab (Zgierz Transport Company Markab) was entrusted with handling a part of one line running through Łódź. It does not change the fact that Łódź is considered to be the only large Polish city in which a municipal company has a monopoly for the provision of transport services. Until the end of 2017, the service of two bus lines (58 and 58A) was, at the request of the city run by the 'KORO' company. Interestingly, the withdrawal from employing the services of this private carrier was a direct result of the city's conclusion of so-called entrustment agreements with Miejskie Przedsiębiorstwo Komunikacyjne (hereafter called MPK): the local government has guaranteed MPK a monopoly on servicing tasks ordered by Zarząd Dróg i Transportu (the Road and Transport Authority). Nevertheless, the MPK operator concluded the contract with 'KORO' for servicing the line as a subcontractor of a municipal company because MPK had problems with ensuring rolling stock. After the expiration of the annual contract, no further tender was called for because MPK considered that it has the capacity to service the line on its own.

In Wrocław, the operator in the bus and tram sectors is MPK. The tenders are organised only for the servicing of suburban lines, for which neighbouring municipalities are the organisers. However, the municipal company does not have sufficient funds to provide self-service to all bus lines, which is why in 2015 it decided to select a subcontractor. Spótka Michalczewski (Michalczewski Company), which has been commissioned for 10 years, is not really an operator but a sub-contractor of the operator.

In Poznań, MPK is the operator of bus and tram transport in the city. Companies owned by neighbouring municipalities - Kórnickie Przedsiębiorstwo Autobusowe 'Kombus' (Kórnickie Bus Company 'Kombus') and Przedsiębiorstwo Ustug Komunalnych Komorniki (Municipal Services Komorniki) - provide transport on suburban lines (Kiciński and Bieńczak, 2014). In this case, Zarzą Transportu Miejskiego (Municipal Transport Authority) is an organiser under inter-municipal agreements.

In Gdańsk, the main operator in the city is Gdańskie Autobusy i Tramwaje (Gdańsk Buses and Trams). It evolved from the budgetary entity in 2004. The company is the exclusive operator of urban transport in the sectors of trams and buses. The suburban lines are served by a private BP Tour company. Interestingly, in the neighbouring municipality, the 
transport market is definitely more fragmented. In addition to several private operators, services for the organiser are provided by two companies owned by the city. Gdańskie Autobusy i Tramwaje are also the operator of two water tram lines in Gdańsk.

An important part of public transport in Gdańsk is rail transport performed by the company Szybka Kolej Miejska - PKP Szybka Kolej Miejska w Trójmieście (Fast Urban Railway). The company is part of the state holding company-the PKP Group. It deals with the management, administration, and service of the Gdańsk-Rumia railway line.

In Szczecin, in the tram sector-as in other Polish cities - we have a monopoly by a company owned by the city of Szczecin. Tram transport is $100 \%$ operated by Tramwaje Szczecinskie (Szczecin Trams). The city concluded a contract with the company until 2026. In the bus sector there was a significant diversification of services. Part of the line is operated by two companies wholly owned by the city: Szczecinskie Przedsiębiorstwo Autobusowe 'Klonowica' (the Szczecin Bus Company 'Klonowica') and Szczecińskie Przedsiębiorstwo Autobusowe 'Dąbie' (the Szczecin Bus Company 'Dąbie'). Bus lines connecting Szczecin and the neighbouring Police municipality are served by another municipal company Szczecinsko-Polickie Przedsiębiorstwo Komunikacyjne (Bus Transport Company in Szczecin and Police) (42.15\% of shares held by the city of Szczecin, and $57.85 \%$ of shares by the Police municipality). To service parts of day and night lines, the city chooses the operator by tender.

Until now, the operator was Przedsiębiorstwo Komunikacji Samochodowej w Szczecinie (Bus Transport Company in Szczecin, hereinafter called PKS) established on the basis of a former state long-distance bus carrier. On December 31, 2017, the contract for the provision of these services expired in favour of Szczecin city. However, the tender, which was issued by Zarząd Dróg i Transportu Miejskiego (the Municipal Road and Transport Company, hereinafter called ZDiTM), aroused numerous controversies. Experts pointed out that both the specification and the short deadline for submitting offers clearly favours the existing operator. Ultimately, apart from PKS in Szczecin there was only Arriva which submitted the tender. However, this was an incomplete offer, not including, for example, such an important component as the price of the service. Therefore, it should be treated as an expression of symbolic opposition to ZDiTM procurement practices (InfoBus.pl, 2018).

Bydgoszcz is the only city in Poland where two companies: MZK and Tramwaj Fordon (Fordon Tram, hereafter called TF) are tram sector operators. TF is an operator on the basis of an agreement with the city. It provides transport services only on one newly created route (the so-called Fordon line). It is also manager of all newly built infrastructure and owns 12 vehicles purchased as part of an investment financed mainly by European funds. For this reason, a solution has been implemented that allows the company to function as an operator. TF carries out about 35\% of all train-kilometres per year. The specific agreement was signed between Zarząd Dróg Miejskich i Komunikacji Publicznej (Municipal Roads and Public Transport Authority) in Bydgoszcz and TF for the provision of transport services and between TF and MZK for subcontracting.

Most of the city bus lines are also serviced in Bydgoszcz by MZK. The last tender for servicing selected bus lines was won by the company Irex-Trans.

In Lublin, the dominant position in the trolleybus and bus sectors is held by a company $100 \%$ owned by the city-MPK Lublin. As a result of tenders, city and suburban lines in Lublin are also served by private carriers. These include two consortia: IREX -1 and $M e-$ teor, as well as Lubelskie Linie Autobusowe (Lublin Bus Company) and TRAF-Line. 
In Białystok, there are three operators in the bus sector: Komunalne Przedsiębiorstwo Komunikacyjne (Municipal Transport Company), Komunalny Zakład Komunikacyjny (Municipal Transport Enterprise) and Komunalne Przedsiębiorstwo Komunikacji Miejskiej (Urban Transport Company). All of them are owned by the city.

In Katowice, Tramwaje Slaskie (Silesian Trams) is in charge of the tram sector and operates in all cities and municipalities of the Upper Silesian Industrial Region in which there is a tram infrastructure. In the bus sector, the operator with the largest share of Katowice is Przedsiębiorstwo Komunikacji Miejskiej Katowic (Municipal Transport Company in Katowice). The city is not the only shareholder of the company, because it is formed by two neighbouring cities: Siemianowice Śląskie (8.5\% of shares) and Chorzów (3.91\% of shares). Bus lines within the city are also served by other operators who make inter-municipal connections: Przedsiębiorstwo Komunikacji Miejskiej Sosnowiec (Municipal Transport Company in Sosnowiec); Przedsiębiorstwo Komunikacji Miejskiej Międzygminna Spółka $z$ o.o. $w$ Świerklańcu (Inter-Municipal Transport Company in Świerklaniec); Przedsiębiorstwo Komunikacji Miejskiej w Gliwicach (Municipal Transport Company in Gliwice). In order to service a few low-cost lines, private operators were selected through tender.

A summary of the applied solutions in the field of management and administration of public urban transport in large Polish cities is presented in the table 1.

Table 1. Organisers and operators of municipal public transport in the largest Polish cities (as of March 2018)

\begin{tabular}{|c|c|c|c|c|c|c|}
\hline City & $\begin{array}{c}\text { Organ- } \\
\text { iser of } \\
\text { munici- } \\
\text { pal public } \\
\text { transport }\end{array}$ & $\begin{array}{l}\text { The unit } \\
\text { responsible } \\
\text { for the or- } \\
\text { ganization } \\
\text { of munici- } \\
\text { pal public } \\
\text { transport }\end{array}$ & $\begin{array}{l}\text { The status } \\
\text { of the unit } \\
\text { responsible } \\
\text { for the or- } \\
\text { ganization } \\
\text { of munici- } \\
\text { pal public } \\
\text { transport }\end{array}$ & $\begin{array}{l}\text { Operators } \\
\text { fully owned } \\
\text { by cities } \\
\text { (municipal } \\
\text { companies) }\end{array}$ & Private operators & Other operators \\
\hline Warszawa & $\begin{array}{c}\text { Mayor of } \\
\text { Warszawa }\end{array}$ & $\begin{array}{c}\text { Zarzad } \\
\text { Transportu } \\
\text { Miejskiego }\end{array}$ & $\begin{array}{l}\text { Budgetary } \\
\text { unit }\end{array}$ & $\begin{array}{c}\text { Miejskie } \\
\text { Zakłady Au- } \\
\text { tobusowe } \\
\text { Tramwaje } \\
\text { Warszawskie } \\
\text { Metro } \\
\text { Warszawskie } \\
\text { Szybka Kolej } \\
\text { Miejska }\end{array}$ & $\begin{array}{c}\text { Mobilis } \\
\text { Arriva Bus Trans- } \\
\text { port Polska } \\
\text { Europa Express City } \\
\text { Przedsiębiorstwo } \\
\text { Komunikacji Samo- } \\
\text { chodowej w Grod- } \\
\text { zisku Mazowieckim } \\
\text { (Bus Transport } \\
\text { Company in Grod- } \\
\text { zisk Mazowiecki) }\end{array}$ & $\begin{array}{l}\text { Komunikacja } \\
\text { Miejska Łomi- } \\
\text { anki (Public } \\
\text { Transport in } \\
\text { Łomianki) }\end{array}$ \\
\hline Kraków & $\begin{array}{l}\text { Mayor of } \\
\text { Kraków }\end{array}$ & $\begin{array}{l}\text { Zarzad In- } \\
\text { frastruktury } \\
\text { Komunalnej } \\
\text { i Transportu } \\
\text { w Krakowie }\end{array}$ & $\begin{array}{l}\text { Budgetary } \\
\text { unit }\end{array}$ & $\begin{array}{l}\text { MPK in } \\
\text { Kraków }\end{array}$ & Mobilis & - \\
\hline
\end{tabular}




\begin{tabular}{|c|c|c|c|c|c|c|}
\hline City & $\begin{array}{c}\text { Organ- } \\
\text { iser of } \\
\text { munici- } \\
\text { pal public } \\
\text { transport }\end{array}$ & $\begin{array}{l}\text { The unit } \\
\text { responsible } \\
\text { for the or- } \\
\text { ganization } \\
\text { of munici- } \\
\text { pal public } \\
\text { transport }\end{array}$ & $\begin{array}{l}\text { The status } \\
\text { of the unit } \\
\text { responsible } \\
\text { for the or- } \\
\text { ganization } \\
\text { of munici- } \\
\text { pal public } \\
\text { transport }\end{array}$ & $\begin{array}{l}\text { Operators } \\
\text { fully owned } \\
\text { by cities } \\
\text { (municipal } \\
\text { companies) }\end{array}$ & Private operators & Other operators \\
\hline Łódź & $\begin{array}{c}\text { Mayor of } \\
\text { Łódz }\end{array}$ & $\begin{array}{l}\text { Zarząd Dróg } \\
i \text { Transportu }\end{array}$ & $\begin{array}{l}\text { Budgetary } \\
\text { unit }\end{array}$ & $M P K-Ł o ́ d z ́$ & BP Tour $r^{* * *}$ & $\begin{array}{c}\text { Zgierskie } \\
\text { Przedsiębiorstwo } \\
\text { Komunikacy- } \\
\text { jne "MARK- } \\
A B \text { " (a part of } \\
\text { inter-municipal } \\
\text { line) - company } \\
\text { with the partic- } \\
\text { ipation of the } \\
\text { city of Zgierz }\end{array}$ \\
\hline Wrocław & $\begin{array}{l}\text { Mayor of } \\
\text { Wrocław }\end{array}$ & $\begin{array}{c}\text { Wydział } \\
\text { Transportu } \\
\text { Urzędu } \\
\text { Miasta }\end{array}$ & $\begin{array}{l}\text { The organ- } \\
\text { isational } \\
\text { unit of the } \\
\text { municipal } \\
\text { office }\end{array}$ & $M P K$ & Michalczewski $i^{* * *}$ & - \\
\hline Poznań & $\begin{array}{l}\text { Mayor of } \\
\text { Poznań }\end{array}$ & $\begin{array}{c}\text { Zarzad } \\
\text { Transportu } \\
\text { Miejskiego }\end{array}$ & $\begin{array}{l}\text { Budgetary } \\
\text { unit }\end{array}$ & $M P K$ & - & $\begin{array}{c}\text { Kórnickie } \\
\text { Przedsiębiorst- } \\
\text { wo Autobusowe } \\
\text { "Kombus" } \\
\text { Przedsiębiorstwo } \\
\text { Usług Komunal- } \\
\text { nych Komorniki }\end{array}$ \\
\hline Gdańsk & $\begin{array}{l}\text { Mayor of } \\
\text { Gdańsk }\end{array}$ & $\begin{array}{c}\text { Zarząd } \\
\text { Transportu } \\
\text { Miejskiego }\end{array}$ & $\begin{array}{l}\text { Budgetary } \\
\text { unit }\end{array}$ & $\begin{array}{c}\text { Gdańskie } \\
\text { Autobusy } \\
\text { i Tramwaje }\end{array}$ & - & - \\
\hline Szczecin & $\begin{array}{l}\text { Mayor of } \\
\text { Szczecin }\end{array}$ & $\begin{array}{c}\text { Zarząd Dróg } \\
\text { i Transportu } \\
\text { Miejskiego }\end{array}$ & $\begin{array}{l}\text { Budgetary } \\
\text { unit }\end{array}$ & $\begin{array}{l}\text { Tramwaje } \\
\text { Szczecińskie } \\
\text { Szczecinsk- } \\
\text { ie Przed- } \\
\text { siębiorstwo } \\
\text { Autobusowe } \\
\text { "Klonowica" } \\
\text { Szczecińsk- } \\
\text { ie Przed- } \\
\text { siębiorstwo } \\
\text { Autobusowe } \\
\text { "Dabie" }\end{array}$ & PKS in Szczecin & $\begin{array}{l}\text { Szczecińsko-Pol- } \\
\text { ickie Przed- } \\
\text { siębiorstwo } \\
\text { Komunikacyjne } \\
\text { (shares: Szczecin } \\
\text { municipali- } \\
\text { ty-42,15\%, } \\
\text { Police munici- } \\
\text { pality 57,85\%) }\end{array}$ \\
\hline Bydgoszcz & $\begin{array}{c}\text { Mayor of } \\
\text { Bydgoszcz }\end{array}$ & $\begin{array}{c}\text { Zarząd Dróg } \\
\text { Miejskich } \\
\text { i Komu- } \\
\text { nikacji } \\
\text { Publicznej }\end{array}$ & $\begin{array}{l}\text { Budgetary } \\
\text { unit }\end{array}$ & $\begin{array}{c}\text { MPK } \\
\text { Tramwaj } \\
\text { Fordon }\end{array}$ & Irex-Trans & - \\
\hline
\end{tabular}




\begin{tabular}{|c|c|c|c|c|c|c|}
\hline City & $\begin{array}{l}\text { Organ- } \\
\text { iser of } \\
\text { munici- } \\
\text { pal public } \\
\text { transport }\end{array}$ & $\begin{array}{l}\text { The unit } \\
\text { responsible } \\
\text { for the or- } \\
\text { ganization } \\
\text { of munici- } \\
\text { pal public } \\
\text { transport }\end{array}$ & $\begin{array}{l}\text { The status } \\
\text { of the unit } \\
\text { responsible } \\
\text { for the or- } \\
\text { ganization } \\
\text { of munici- } \\
\text { pal public } \\
\text { transport }\end{array}$ & $\begin{array}{l}\text { Operators } \\
\text { fully owned } \\
\text { by cities } \\
\text { (municipal } \\
\text { companies) }\end{array}$ & Private operators & Other operators \\
\hline Lublin & $\begin{array}{l}\text { Mayor of } \\
\text { Lublin }\end{array}$ & $\begin{array}{c}\text { Zarzad } \\
\text { Transportu } \\
\text { Miejskiego }\end{array}$ & $\begin{array}{c}\text { Budgetary } \\
\text { unit }\end{array}$ & MPK Lublin & $\begin{array}{c}\text { Consortium: Irex-1 } \\
\quad+\text { Meteor } \\
\text { Consortium: Lubel- } \\
\text { skie Linie Autobu- } \\
\text { sowe +TRAF-Line }\end{array}$ & - \\
\hline Białystok & $\begin{array}{l}\text { Mayor of } \\
\text { Białystok }\end{array}$ & $\begin{array}{c}\text { Zarząd } \\
\text { Białostockiej } \\
\text { Komunikac- } \\
\text { ji Miejskiej }\end{array}$ & $\begin{array}{l}\text { The organ- } \\
\text { isational } \\
\text { unit of the } \\
\text { municipal } \\
\text { office }\end{array}$ & $\begin{array}{c}\text { Komunalne } \\
\text { Przedsiębi- } \\
\text { orstwo Komu- } \\
\text { nikacyjne Sp. } \\
\text { zo.o. } \\
\text { Komunalny } \\
\text { Zakład Ko- } \\
\text { munikacyjny } \\
\text { Sp. zo.o. } \\
\text { Komunalne } \\
\text { Przed- } \\
\text { siębiorstwo } \\
\text { Komunikacji } \\
\text { Miejskiej Sp. } \\
\text { zo.o. }\end{array}$ & - & - \\
\hline Katowice & $\begin{array}{l}\text { Mayor of } \\
\text { Katowice }\end{array}$ & $\begin{array}{c}\text { Komu- } \\
\text { nikacyjny } \\
\text { Związek } \\
\text { Komunalny } \\
\text { Górnoślask- } \\
\text { iego Okręu } \\
\text { Przemys- } \\
\text { łowego } \\
\text { (Municipal } \\
\text { Transport } \\
\text { Union of } \\
\text { the Upper } \\
\text { Silesian } \\
\text { Industrial } \\
\text { District) }\end{array}$ & $\begin{array}{l}\text { Inter-mu- } \\
\text { nicipal } \\
\text { association }\end{array}$ & $\begin{array}{c}\text { Tramwaje } \\
\text { Śląskie } \\
\text { Przed- } \\
\text { siębiorstwo } \\
\text { Komunikacji } \\
\text { Miejskiej } \\
\text { Katowice }\end{array}$ & $\begin{array}{c}\text { Lazar } \\
\text { Consortium: } \\
\text { IREX-Meteor } \\
\text { A21 } \\
\text { Meteor } \\
\text { Intrans } \\
\text { Murgór Trans } \\
\text { Brożek }\end{array}$ & $\begin{array}{c}\text { Przedsiębiorstwo } \\
\text { Komunikacji } \\
\text { Miejskiej Sos- } \\
\text { nowiec } \\
\text { Przedsiębiorstwo } \\
\text { Komunikac- } \\
\text { ji Miejskiej } \\
\text { Międzygminna } \\
\text { in Świerklaniec } \\
\text { Przedsiębiorstwo } \\
\text { Komunikacji } \\
\text { Miejskiej in } \\
\text { Gliwice }\end{array}$ \\
\hline
\end{tabular}

Source: Own elaboration.

* Belongs to KZK GOP.

** A small part of shares is also owned by the cities Siemianowice Śl. and Chorzów.

$* * *$ As a subcontractor.

**** Till December 2017 - the tender procedure is currently underway. 


\section{Management and administration of municipal public transport in Polish cities - the target state}

The authors of the transport strategy for Warsaw did not explicitly state how much transport in the bus segment should remain in the hands of a company owned by the city. They only stated that it must be the majority of transport work (Plan Transportowy (PT) Warsaw, p. 73). The argument in favour of leaving this transport under full control of the city was to ensure the strategic security of this system. When it comes to the tram and metro seectors, the city authorities clearly indicated that in the near future they do not plan to entrust any private entity with the role of the operator at all.

In Krakow, the authors of the strategy set the target level of the share of services contracted by a company belonging to the city in the bus sector at a ceiling of $85 \%$. It would mean that only $15 \%$ of transport work would be performed by private operators (PT Krakow, p. 129). There is no clear information about such a division in other sectors of municipal transport.

In Łódź, the council adopted a transportation development strategy no earlier than February 2018. It does not contain detailed guidelines regarding the division between the transport work performed under the contract of entrustment and that performed on the basis of contracts concluded after the tender allotment. The authors of the strategy negatively assessed the fact of monopolising the public services market by the municipal company and assumed that by 2020 the city should decide to organise tenders in such a way that the transport performance of MPK Łódź would decrease to about $70 \%$ of all transport operations (PT Łódź, p. 72). In fact, there was only one tender in 2020 and MPK Łódź is still operating almost $100 \%$ of bus lines.

In the transport development strategy for Wrocław, the authors did not decide to enter into detailed guidelines regarding the way the operators, whose task is to service urban lines, will be selected. Only the practices in suburban transport (cooperation with other municipalities) and data from other cities were referred to. It was concluded that in Krakow and Warsaw about $20 \%$ of bus transport work is ordered through a tender. Wrocław should not exclude such a possibility, especially when the capacity of MPK is not available (PT Wrocław, p. 98).

In Poznan, the authors of the strategy did not specify the percentage of private operators' share in the transport market in the city. They accepted the general statement that one cannot eliminate in the future any form of transfer to service selected bus lines specified in the act on public transport (PT Poznań, p. 90). It was only emphasised that the organisation of future tenders should be based on the differentiation of the subject matter of the contract. A part of the tenders would concern the service of individual lines (e.g. agglomeration ones), another part-packages of several lines, while several tenders may concern multi-line packages, e.g. for servicing a city or a specific area (PT Poznań, p. 90).

In Gdańsk, the authors of the strategy assumed that the optimal structure of the market is $85.50 \%$ share of the municipal operator in bus transport and $100 \%$ in tram transport (PT Gdańsk, p. 98). The coefficient determined for bus transport resulted from the current traffic situation in Gdańsk - at the time of creating the strategy, the municipal company ZKM had such a share in overall transport work in Gdańsk. Interestingly, in the strategy for Gdańsk - and it should be considered as being exceptional - it was clearly demonstrated that the bus sector is a transportation-supply type, which means granting priority 
to rail transport: trams, high-speed rail and the Pomeranian Metropolitan Railway (PT Gdańsk, p. 93).

In Szczecin, strategic goals related to the division of transport tasks between private operators selected under the tender procedure and operators owned by the city were not defined. The example of entrusting a task in the form of handling night transport in a non-procedural manner is referred to as a benchmark for constructing public procurement specifications (PT Szczecin, p. 87).

The transport development strategy for Bydgoszcz, prepared by experts assumes the achievement of a coefficient of $70 \%$ of the total transport work for MZK, i.e. a company controlled entirely by the city (PT Bydgoszcz, p. 138). All transport work in the tram sector is to be entrusted to a subsidiary of the city - ultimately, this will be Tramwaje Bydgoskie (Bydgoszcz Trams) (PT Bydgoszcz, p. 139). Currently, as a consequence of the European Union project (a tram line connecting the Fordon district with the centre), there are two such companies: Tramwaj Fordon and MZK.

The Lublin transport development strategy assumes that the share of private operators on the market of public transport services will increase to $20-30 \%$. It specified that $70-80 \%$ of transport performance should be performed by a municipal company through a contract of entrustment (PT Lublin, p. 123). However, the authors did not indicate a breakdown of transport performance in the bus and trolleybus sectors; therefore it is not known what this share in individual sectors will look like. In Lublin's strategy, which is worth noting, the superiority of the competitive market over the market monopolised by the municipal company is clearly emphasised.

The authors point out that a high share of the operator, owned solely by the city of Lublin, "may be a threat to the provision of services at a level corresponding to the preferences and expectations of passengers. There is, however, a risk of a conflict of interest: on one hand, an urban company with a strong market position, whose activity is aimed at maximising economic and financial efficiency, and on the other hand-a transport organiser who shapes specific transport and social policy objectives." (PT Lublin, p. 122).

The Białystok transport development strategy assumes that there will be still three operators of the bus services in the city. The authors claim also that it is permissible - if there is a need - to open the bus sector to other operators (PT Białystok, p. 173).

The development plan of Katowice's transport system focuses primarily on infrastructure tasks that will improve the quality of transport and passenger satisfaction. The strategic objectives and the timetable for their implementation were precisely defined, but the issue of transport organisation was not referred to at all (but - as we have stated above - the function of the public transport organizer in Katowice is fulfilled mainly by the Board of Metropolitan Transport).

A summary of the analysis of transport plans to the extent to which it concerned the organisation of urban transport is presented in the table 2 . 
Table 2. Assumed share of municipal companies in providing public transport services in the largest Polish cities

\begin{tabular}{|c|c|c|}
\hline City & Bus segment & Tram/trolley bus \\
\hline Warszawa & circa $70 \%$ & $100 \%$ \\
\hline Kraków & $85 \%$ & Without plans \\
\hline Łódź & circa $70 \%$ & Without plans \\
\hline Wrocław & $\begin{array}{c}100 \% \\
\text { (with acceptable private subcontractor) }\end{array}$ & Without plans \\
\hline Poznań & \multicolumn{2}{|c|}{ Without plans } \\
\hline Gdańsk & $85,50 \%$ & $100 \%$ \\
\hline Szczecin & circa $75 \%$ & Without plans \\
\hline Bydgoszcz & $70 \%$ & $100 \%$ \\
\hline Lublin & \multicolumn{2}{|c|}{$70-80 \%$} \\
\hline Białystok & Without plans & Not applicable \\
\hline Katowice & \multicolumn{2}{|c|}{ Without plans } \\
\hline
\end{tabular}

Source: own analysis based on transport plans of individual cities and TOR, 2019, p. 60.

\section{Conclusion}

Since Zatti published his report, in which he did not clearly indicate which model of administrative-public transport solutions was implemented in Poland (Zatti, 2011), the law has changed significantly. In 2010, the Parliament passed a law on public transport, which was to establish clear rules of conduct and indicate the responsibility and expected model of organisation of transport not only on the scale of the municipality (city), but also the county and the region.

However, this act did not cause any real, sudden changes. There were two reasons for this: first, the legislator is still amending the bill and - what is more-announcing another thorough reform; and secondly - there is a strong resistance in the cities against changes. Cities want to maintain their influence on the quality and frequency of connections. In addition, they must bear in mind that for many years there have been many transport companies operating, companies which belong to them entirely. On the basis of the analysis of the eleven largest Polish cities, however, one can develop a comparative model of adopted solutions (a summary of public transport organisation in the largest Polish cities).

In the Polish legal system, it is the municipality which is the organiser of municipal public transport. The Mayor is the municipality's executive body in the large cities. He appoints a specialised unit that acts as an organiser of urban transport on his behalf and is responsible for activities in this area. All such units have their statutes and are directly dependent on Mayor (although some political decisions on public transport - such as ticket prices - should be approved by the city council).

The operators in the tram sector in all cities are companies owned by these cities. One can therefore speak of a full monopoly in the provision of these services. (The exception is Katowice, which cooperates in this respect with other cities and forms the GZM Me- 
tropolis). This is caused - to a certain extent - by the lack of statutory solutions regarding the division of responsibility for infrastructure maintenance and a small number of companies that would be interested in short (up to 10-year) contracts for such transport. The scope of rolling stock investments that would be required to undertake transport tasks in the field of tram transport seem unprofitable at the moment.

The dominant operators in the bus sector are also $100 \%$ city owned companies. Their market share is $80-100 \%$ of transport work. The companies operate bus lines on the basis of long-term entrustment contracts. The organisers commission the remaining $0-20 \%$ of transport work by competitive tender. The companies may compete for the service of specific lines or line packages designated in advance by the organiser. They can also compete for the performance of an order for transport work counted in vehicle kilometres travelled. Only in Wrocław and Łódź can you find an example of the combined model. Although the cities commission $100 \%$ of the transport work to the company which it owns, this company chooses a subcontractor by tender, which provides its service under a separate agreement.

The biggest problem of Polish big cities, however, is that: in the transport plans in which clear targets could have been set regarding the participation of private entities and municipal companies in the process of providing transport services, they were not set, or it was done very conservatively. In the eleven analysed cases, as many as five did not address this issue at all, and in two - no targets in the tramway sector were defined. The authors of the transport development strategy recognised that the only sector in which a formula of market competition can be allowed is bus transport. At the same time, it is not expected of any of the big cities to be more open to private operators in the future than at present. In cities in which they decided to do so it was assumed that the maximum ceiling for the participation of private operators would be at the level of $30 \%$.

It can also be clearly seen that in the design of public transport, the railway potential is not used at all. The processes of suburbanisation are not accompanied by such changes in the law that could improve access to the centres of big cities and facilitate everyday commuting to school or work. The potential remains unused despite the fact that railway lines in all large Polish cities run through their centres. The function of the organisers of urban transport in large cities is taken over by local governments that perform rail transport services through the rail companies they control. However, until the railway sector is considered the domain of regional transport, it will not be fully used to improve the quality of public transport in large Polish cities.

\section{References}

Barber, B., 2017. Cool Cities: Urban Sovereignty and the Fix for Global Warming. Yale University Press, New Haven - London.

Barber, B., 2014. If Mayors Ruled the World: Dysfunctional Nations, Rising Cities. Yale University Press, New Haven - London.

Cantwell, M., Caulfield, B., O’Mahony, M., 2009. Examining the Factors that Impact Public Transport Commuting Satisfaction. Journal of Public Transportation 12, 21.

Dydkowski, G., 2015. Zarządy transportu miejskiego w Polsce-przesłanki tworzenia oraz organizacyjno-prawne formy działalności. Studia Ekonomiczne 39-57.

Endicott, T., 2015. Administrative Law, 3rd ed. Oxford University Press, Oxford. 
Fellesson, M., Friman, M., 2012. Perceived Satisfaction with Public Transport Service in Nine European Cities. Journal of the Transportation Research Forum 47. https://doi. org/10.5399/osu/jtrf.47.3.2126

Gallez, C., Kaufmann, V., Maksim, H., Thebért, M., Guerrinha, C., 2013. Coordinating Transport and Urban Planning: From Ideologies to Local Realities. European Planning Studies 21, 1235-1255. https://doi.org/10.1080/09654313.2012.722945

Giorgi, L., Schmidt, M., 2006. European Transport Policy: A Historical and Forward Looking Perspective. German Policy Studies/Politikfeldanalyse 3, 1-19.

Glaeser, E., 2011. Triumph of the City: How Our Greatest Invention Makes Us Richer, Smarter, Greener, Healthier, and Happier. Penguin Books, New York.

Grondys, K., Kott, I., Sukiennik, K., 2017. Funkcjonowanie polskich miast w dobie zrównoważonego rozwoju z punktu widzenia transportu. Zeszyty Naukowe Politechniki Częstochowskiej Zarządzanie 25, 237-245. https://doi.org/10.17512/znpcz.2017.1.1.21

Gualdi, M., Sessa, C., 2002. Impacts of Institutional Change on Urban Transport Policy in Rome: An Update. German Policy Studies/Politikfeldanalyse 2.

GUS, 2019. Rocznik demograficzny. Demographic Yearbook of Poland. https://stat.gov.pl/ download/gfx/portalinformacyjny/pl/defaultaktualnosci/5515/3/13/1/rocznik_demograficzny_2019.pdf.

Heddebaut, O., Di Ciommo, F., 2018. City-hubs for smarter cities. The case of Lille "EuraFlandres" interchange. European Transport Research Review 10. https://doi. org/10.1007/s12544-017-0283-3

Kahn-Freund, O., 1974. On Uses and Misuses of Comparative Law. The Modern Law Review 37, 1-27.

Kamba, W.J., 1974. Comparative Law: A Theoretical Framework. The International and Comparative Law Quarterly 23, 485-519.

Katz, B.J., Bradley, J., 2014. The Metropolitan Revolution: How Cities and Metros Are Fixing Our Broken Politics and Fragile Economy. Brookings Institution Press, Washington.

Khan, S., Khan, M., 2012. Community Bus in Tokyo: Promoting Community Initiative through Decentralisation. Space and Polity 16, 129-151. https://doi.org/10.1080/135625 76.2012.698140

Kiciński, M., Bieńczak, M., 2014. Tendencje zmian kosztów funkcjonowania przedsiębiorstwa publicznego transportu autobusowego na przykładzie KPA Kombus Sp. z o.o. w Kórniku. Logistyka 3, 2870-2878.

Kowalski, M., Nesterak, J., Wodyński, S., Żelaszczyk, A., 2013, Performance Management w zarządzaniu rentownością kursów przewozowych w kontekście krajowych zmian prawnych regulujących publiczny transport zbiorowy. Autobusy: technika, eksploatacja, systemy transportowe 14(6), 18-24.

Massey, P., 2014. Bus Competition in Ireland: Delayed by Regulatory Roadblocks. Economic Affairs 34, 319-334.

Regulation (EC) No 1370/2007 of the European Parliament and of the Council of 23 October 2007 on public passenger transport services by rail and by road and repealing Council Regulations (EEC). Nos 1191/69 and 1107/70, 2007.

Rek-Woźniak, M., 2017. "Anatomia ambicji” a polityka publiczna. Cztery wątki debaty o miejskich megaprojektach. Problemy polityki społecznej. Studia i dyskusje 37, 117137. 
Sager, F., 2005. Metropolitan institutions and policy coordination: the integration of land use and transport policies in Swiss urban areas. Governance 18, 227-256.

Solecka, K., 2011. Integration of public transport in Polish and EU documents and examples of solutions for integration of public transport in Poland and in the world. Transport Problems 6, 23-34.

Sońta, W., 2012, Zmiany organizacyjno-prawne przedsiębiorstw transportu miejskiego. Autobusy: technika, eksploatacja, systemy transportowe 13(10), 28-32.

Sopoćko, M., Caban, J., Marczuk, A., Komsta, H., 2016. Rozwój i zarządzanie komunikacją miejską w Lublinie. Autobusy: technika, eksploatacja, systemy transportowe 17(12), $1858-1862$.

Taylor, Z., Ciechański, A., 2015. Control functions within large cities and foreign direct investment in the transport sector: Empirical evidence from Poland. Geographia Polonica 88, 557-573. https://doi.org/10.7163/GPol.0034

Taylor, Z., Ciechański, A., 2014. Funkcje kontrolne wielkich miast Polski w świetle bezpośrednich inwestycji zagranicznych w transporcie. Przegląd Geograficzny 86, 141-170. https://doi.org/10.7163/PrzG.2014.2.1

Taylor, Z., Ciechański, A., 2010. Organizational and Ownership Transformation in Poland's Urban Transport Companies. Transport Reviews 30, 407-434. https://doi. org/10.1080/01441640903034369

Taylor, Z., Ciechański, A., 2009. Przekształcenia własnościowe przedsiębiorstw transportu miejskiego w Polsce-część II. Przegląd Geograficzny 81, 205-236.

Tomaszyk, M., 2016. Przykłady działań polskich i niemieckich organizatorów publicznego transportu zbiorowego na rzecz partycypacji mieszkańców miast w bieżącym koordynowaniu i zarządzaniu siecią transportu miejskiego. Przegląd Politologiczny 207. https://doi.org/10.14746/pp.2016.21.4.16.

TOR, 2019, Liberalizacja rynku miejskich przewozów autobusowych, https://zdgtor.pl/ publication/liberalizacja-rynku-miejskich-przewozow-autobusowych/.

Treaty on the Functioning of the European Union, 2007.

Turner, J., Holmes, L., Hodgson, F.C., 2000. Intelligent urban development: An introduction to a participatory approach $37,1723-1734$.

Uspalyte-Vitkuniene, R., Burinskiene, M., 2007. Determination of factors that influence public transport. WIT Press, pp. 327-336. https://doi.org/10.2495/UT070311

Ustawa z dnia 8 marca 1990 r. o samorządzie gminnym, 1990.

Ustawa z dnia 9 marca 2017 roku o związku metropolitalnym w województwie śląskim, 2017.

Ustawa z dnia 15 marca 2002 roku o ustroju miasta stołecznego Warszawy, 2002.

Ustawa z dnia 16 grudnia 2010 r. o publicznym transporcie zbiorowym, 2010.

Zatti, A., 2012. New Organizational Models in European Local Public Transport. From Myth to Reality. Annals of Public and Cooperative Economics 83, 533-559. https://doi. org/10.1111/j.1467-8292.2012.00476.x

Zatti, A., 2011. New organizational models in European Local Public Transport: from Myth to Reality (No. 2011/06). CIRIEC International Scientific Commission on "Public Services / Public Enterprises". 